\title{
PEMBUATAN LOTION TABIR SURYA TEPUNG TULANG SOTONG (Sepia officinalis) DENGAN PERBANDINGAN EMULGATOR
}

\author{
Mensie Martha Lovianie ${ }^{1}$ \\ ${ }^{1}$ STIKes Borneo Cendekia Medika Pangkalan Bun \\ ${ }^{1}$ Email : mensiemartha@34gmail.com
}

\begin{abstract}
ABSTRAK
Telah dilakukan penelitian yang berjudul Pembuatan Lotion Tabir Surya Tepung Tulang Sotong Dengan Perbandingan Emulgator. Penelitian ini bertujuan untuk menentukan emulgator yang menghasilkan formula sedian lotion yang memiliki kestabilan organoleptis, homogenitas, $\mathrm{pH}$, dan iritasi sediaan yang paling baik. Formula lotion tepung tulang sotong dibuat dengan menggunakan emulgator anionik dengan konsentrasi asam stearat $8 \%$ dan trietanolamin $4 \%$, nonionik dengan dengan konsentrasi span $603 \%$ dan tween 80 10\%. Pengujian kestabilan lotion dilakukan sebelum dan sesudah kondisi dipercepat pada suhu $5^{\circ} \mathrm{C}$ dan $35^{\circ} \mathrm{C}$ selama 12 jam secara bergantian sebanyak 10 siklus. Hasil penelitian menunjukan bahwa formula nonionik merupakan sediaan lotion yang paling baik dalam penelitian ini.
\end{abstract}

Kata kunci : Lotion, Tulang Sotong, Anionik, Nonionik, dan Uji Stabilitas Fisik.

\section{MAKING OF SURYA TABIR LOTION FLOUR SOTONG FLOUR (Sepia officinalis) WITH COMPARISON OF EMULGATORS}

\begin{abstract}
A research entitled "The Making of Sunscreen Lotion with Cuttlefish Flour with Emulgator Comparison". This study aims to determine the emulgator that produces a sedion lotion formula that has the best organoleptic stability, homogeneity, $\mathrm{pH}$, and irritation of the preparation. Cuttlefish flour lotion formula is made using anionic emulgator with a concentration of stearic acid $8 \%$ and triethanolamine $4 \%$, nonionic with a concentration span of $603 \%$ and tween $8010 \%$. The lotion stability test is carried out before and after the condition is accelerated at a temperature of $5^{\wedge}\left({ }^{\circ}\right) C$ and $35 \wedge\left({ }^{\circ}\right) C$ for 12 hours alternately for 10 cycles. The results showed that the nonionic formula was the best lotion preparation in this study.
\end{abstract}

Keywords: Lotion, Cuttlefish Bone, Anionic, Nonionic, and Physical Stability Test.

\section{PENDAHULUAN}

Radiasi sinar UV yang merupakan salah satu penyebab kerusakan kulit, tentunya menjadi masalah yang patut diperhatikan, terlebih akhir-akhir ini diperparah oleh menipisnya lapisan ozon di atmosfir bumi sehingga dampak dari paparan sinar UV semakin terasa. Radiasi UV pada panjang gelombang 320-400 nm (UV A) menyebabkan warna kulit menjadi coklat dengan kemerahan ini berbahaya karena dapat menyebabkan penuaan dini dan kanker. Sinar UV dengan panjang gelombang 290-320 
nm (UV B) sering disebut sebagai sinar terbakar (sunburn spectrum) karena sinar ini menjadi penyebab utama dan juga paling efektif menyebabkan pigmentasi. Sinar dengan panjang gelombang 100-290 nm (UV C) merupakan sinar yang tidak sampai ke bumi karena mengalami penyerapan oleh atmosfer. Namun seseorang dapat terkena paparan sinar UV-C dari lampu-lampu buatan dan akibatnya adalah kemerahan kulit, peradangan mata, dan merangsang pigmentasi (Tahir, 2000).

Oleh karena itu, diperlukan adanya suatu aktivitas tabir surya yang dapat melindungi kulit dari paparan sinar matahari tersebut. Senyawa tabir surya merupakan suatu senyawa yang dapat digunakan untuk menyerap radiasi sinar matahari terutama pada daerah emisi panjang gelombang Ultraviolet (UV). Senyawa ini akan dapat mencegah terjadinya gangguan kulit akibat pajanan sinar matahari.

Sotong merupakan hewan yang hidup di perairan, khususnya di laut pada kedalaman bervariasi, dari permukaan hingga beberapa ribu meter di bawah permukaan. Sotong memiliki cangkang unik dan berfungsi ganda baik dari memberikan kekokohan pada tubuhnya juga sebagai daya apung dalam pergerakan di air. Cangkang ini sering juga disebut dengan tulang sotong yang mengandung senyawa organik (kitin) dan anorganik ( $\mathrm{Na}, \mathrm{Mg}$, $\mathrm{K}$ dan Ca) (Yildirim et al., 2007). Dari hasil penelitian yang dilakukan oleh Dian Khairunisa (2011), tepung tulang sotong memiliki nilai SPF maksimal 15,13 pada konsentrasi $40 \mu \mathrm{g} / \mathrm{mL}$. Untuk mendukung data ilmiah dari tepung tulang sotong sebagai tabir surya, maka perlu dibuat suatu sediaan yang menarik dan tahan lama, salah satunya dalam bentuk sediaan lotion.
Lotion merupakan salah satu bentuk sediaan farmasi banyak digunakan pada kulit sebagai pelindung atau pengobatan karena sifat bahanbahannya (Ansel, 1989). Sediaan ini juga berfungsi sebagai pelembut dan pelicin kulit karena mengandung bahan yang dapat melembutkan kulit (emolien) yaitu diantaranya setil alkohol. Umumnya lotion diformulasikan dalam bentuk emulsi tipe $\mathrm{M} / \mathrm{A}$, karena memberikan penampakan yang menarik dan mudah dibersihkan. Pada pembuatan lotion ini, digunakan emulgator yang berbeda yaitu emulgator anionik dan nonionik dengan tujuan untuk menentukan emulgator yang paling stabil untuk lotion tabir surya tepung tulang sotong.

\section{METODE PENELITIAN}

\section{Alat-alat Penelitian}

Alat-alat yang digunakan dalam penelitian ini adalah neraca analitik, sendok tanduk, cawan porselin, batang pengaduk, mortir, stamper, cawan petri, inkubator, kulkas, dan alat-alat gelas lain yang sering digunakan di laboratorium.

\section{Bahan Penelitian}

Bahan yang digunakan dalam penelitian ini adalah tepung tulang sotong, asam stearat, trietanolamin, span 60, tween 80, DMDM hydantoin, setil alkohol, gliserin, $\alpha$ tokoferol, dan air suling.

\section{Prosedur Kerja}

\section{a. Pengambilan sampel}

Sampel yang digunakan adalah tepung tulang sotong diambil di pasar Dahlia, Pontianak Barat, Kalimantan Barat.

\section{b. Pengolahan sampel}




\section{HASIL DAN PEMBAHASAN}

Komposisi lotion terdiri dari bahan aktif dan basis. Dalam penelitian ini digunakan tepung tulang sotong sebagai bahan aktif, sedangkan basis yang digunakan terdiri dari asam stearat dan trietanolamina sebagai emulgator anionik, span 60 dan tween 80 sebagai emulgator nonionik, DMDM hydantoin sebagai pengawet, gliserin sebagai humektan, setil alkohol sebagai emolient, $\alpha$-tokoferol sebagai water repellent, dan air suling sebagai pengencer fase. Kondisi penyimpanan dipercepat digunakan untuk mengetahui kestabilan lotion selama penyimpanan yang digunakan, penyimpanan yang dilakukan pada dua kondisi yang berbeda pada suhu $5^{\circ} \mathrm{C}$ dan $35^{\circ} \mathrm{C}$ selama 10 siklus. Kedua kondisi ini mendekati penyimpanan yang realistis 12 sampai 18 bulan pada temperatur kamar (Lachman, 1994).

\section{Pengujian Organoleptis}

Uji organoleptis merupakan salah satu parameter fisik untuk mengetahui kestabilan lotion. Terjadinya perubahan organoleptis yang berupa bentuk, tekstur bau dan warna lotion dapat menggambarkan adanya perubahan kualitas atau ketidakstabilan lotion, pengujian organoleptis dilakukan oleh lima orang sukarelawan dengan membandingkan lotion pada masing-masing formula.

Hasil pengujian organoleptis terhadap lotion sebelum dan sesudah kondisi dipercepat dapat dilihat pada tabel 1 .
Tabel 1 Data Hasil Pengujian Organoleptis Terhadap Lotion Tepung Tulang Sotong Sebelum dan Setelah Kondisi Dipercepat

\begin{tabular}{|c|c|c|c|c|c|c|c|c|}
\hline \multirow{2}{*}{$\begin{array}{c}\text { For } \\
\text { mul } \\
\mathbf{a}\end{array}$} & \multirow{2}{*}{ : } & \multicolumn{3}{|c|}{$\begin{array}{c}\text { Kondisi } \\
\text { Sebelum } \\
\text { Dipercepat }\end{array}$} & \multicolumn{3}{|c|}{$\begin{array}{c}\text { Kondisi } \\
\text { Sesudah } \\
\text { Dipercepat }\end{array}$} & \multirow{2}{*}{$\begin{array}{c}\text { Kete } \\
\text { rang } \\
\text { an }\end{array}$} \\
\hline & & $\begin{array}{c}\text { Te } \\
\text { kst } \\
\text { ur }\end{array}$ & $\begin{array}{l}\text { Wa } \\
\text { rna }\end{array}$ & $\begin{array}{c}\mathbf{B a} \\
\mathbf{u}\end{array}$ & $\begin{array}{l}\text { Te } \\
\text { kst } \\
\text { ur }\end{array}$ & $\begin{array}{c}\text { wa } \\
\text { rn } \\
\mathbf{a}\end{array}$ & $\begin{array}{c}\mathbf{B a} \\
\mathbf{u}\end{array}$ & \\
\hline \multirow{3}{*}{$\begin{array}{l}\text { Ani } \\
\text { onik }\end{array}$} & 1 & $\begin{array}{c}\text { Le } \\
\text { mb } \\
\text { ut }\end{array}$ & $\begin{array}{c}\text { Puti } \\
\text { h }\end{array}$ & $\begin{array}{l}\mathrm{Kh} \\
\text { as }\end{array}$ & $\begin{array}{l}\text { Le } \\
\text { mb } \\
\text { ut }\end{array}$ & $\begin{array}{l}\mathrm{Pu} \\
\text { tih }\end{array}$ & $\begin{array}{c}\mathrm{Kh} \\
\text { as }\end{array}$ & $\begin{array}{c}\text { Tidak } \\
\text { terbe } \\
\text { ntuk } \\
\text { lapisa } \\
\text { n }\end{array}$ \\
\hline & 2 & $\begin{array}{l}\text { Le } \\
\text { mb } \\
\text { ut }\end{array}$ & $\begin{array}{c}\text { Puti } \\
\text { h }\end{array}$ & $\begin{array}{l}\mathrm{Kh} \\
\text { as }\end{array}$ & $\begin{array}{l}\text { Le } \\
\text { mb } \\
\text { ut }\end{array}$ & $\begin{array}{l}\mathrm{Pu} \\
\text { tih }\end{array}$ & $\begin{array}{l}\mathrm{Kh} \\
\text { as }\end{array}$ & $\begin{array}{l}\text { Tidak } \\
\text { terbe } \\
\text { ntuk } \\
\text { lapisa } \\
\text { n }\end{array}$ \\
\hline & 3 & $\begin{array}{c}\text { Le } \\
\text { mb } \\
\text { ut }\end{array}$ & $\begin{array}{c}\text { Puti } \\
\text { h }\end{array}$ & $\begin{array}{l}\mathrm{Kh} \\
\text { as }\end{array}$ & $\begin{array}{l}\text { Le } \\
\text { mb } \\
\text { ut }\end{array}$ & $\begin{array}{l}\mathrm{Pu} \\
\text { tih }\end{array}$ & $\begin{array}{l}\mathrm{Kh} \\
\text { as }\end{array}$ & $\begin{array}{l}\text { Tidak } \\
\text { terbe } \\
\text { ntuk } \\
\text { lapisa } \\
\text { n }\end{array}$ \\
\hline \multirow{3}{*}{$\begin{array}{c}\text { Non } \\
\text { ioni } \\
\mathbf{k}\end{array}$} & 1 & $\begin{array}{c}\text { Le } \\
\text { mb } \\
\text { ut }\end{array}$ & $\begin{array}{c}\text { Puti } \\
\text { h }\end{array}$ & $\begin{array}{l}\mathrm{Kh} \\
\text { as }\end{array}$ & $\begin{array}{l}\text { Le } \\
\text { mb } \\
\text { ut }\end{array}$ & $\begin{array}{l}\mathrm{Pu} \\
\text { tih }\end{array}$ & $\begin{array}{c}\mathrm{Kh} \\
\text { as }\end{array}$ & $\begin{array}{l}\text { Tidak } \\
\text { terbe } \\
\text { ntuk } \\
\text { lapisa } \\
\text { n }\end{array}$ \\
\hline & 2 & $\begin{array}{c}\text { Le } \\
\text { mb } \\
\text { ut }\end{array}$ & $\begin{array}{c}\text { Puti } \\
\text { h }\end{array}$ & $\begin{array}{c}\mathrm{Kh} \\
\text { as }\end{array}$ & $\begin{array}{c}\text { Le } \\
\text { mb } \\
\text { ut }\end{array}$ & $\begin{array}{l}\mathrm{Pu} \\
\text { tih }\end{array}$ & $\begin{array}{c}\mathrm{Kh} \\
\text { as }\end{array}$ & $\begin{array}{l}\text { Tidak } \\
\text { terbe } \\
\text { ntuk } \\
\text { lapisa } \\
\text { n }\end{array}$ \\
\hline & 3 & $\begin{array}{c}\text { Le } \\
\text { mb } \\
\text { ut }\end{array}$ & $\begin{array}{c}\text { Puti } \\
\text { h }\end{array}$ & $\begin{array}{l}\mathrm{Kh} \\
\text { as }\end{array}$ & $\begin{array}{c}\mathrm{Le} \\
\mathrm{mb} \\
\mathrm{ut}\end{array}$ & $\begin{array}{l}\mathrm{Pu} \\
\text { tih }\end{array}$ & $\begin{array}{c}\mathrm{Kh} \\
\text { as }\end{array}$ & $\begin{array}{l}\text { Tidak } \\
\text { terbe } \\
\text { ntuk } \\
\text { lapisa } \\
n\end{array}$ \\
\hline
\end{tabular}

Keterangan :

Anionik : Asam Stearat :

TEA $=8 \%: 4 \%$

Nonionik : Span 60 :

Tween $80=3 \%: 10 \%$

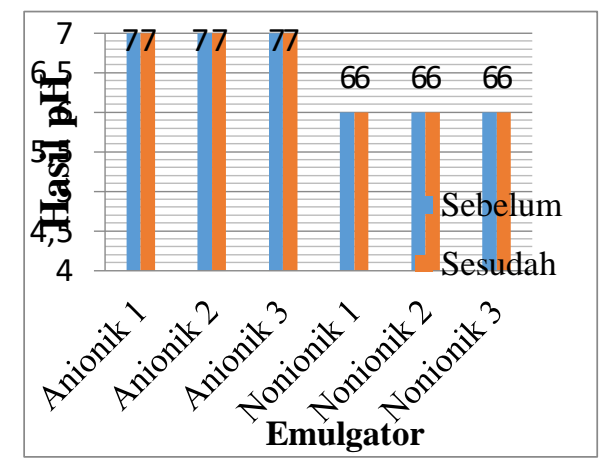


Berdasarkan hasil pengujian diatas diketahui bahwa formula anionik dan nonionik tidak menunjukkan adanya perubahan tekstur, warna dan bau pada kondisi sebelum dipercepat dan setelah kondisi dipercepat.

\section{Pengujian Homogenitas}

Parameter lain yang penting untuk diperhatikan adalah pengujian homogenitas lotion. Lotion harus mempunyai massa yang homogen. Pada pengujian tidak boleh terdapat benda padat saat dioleskan merata pada kacabening. Uji ini dilakukan pada kondisi sebelum dipercepat dan setelah dipercepat. Berdasarkan dari hasil pengamatan, diketahui pada formula anionik dan nonionik memiliki homogenitas yang baik, karena formula anionik dan nonionik tidak menunjukkan adanya bahan padat pada saat dioleskan.

Tabel2 Data Hasil Pengujian Homogenitas Terhadap Lotion Tabir Surya Tepung Tulang Sotong Sebelum dan Setelah Kondisi Dipercepat

\begin{tabular}{|c|c|c|c|}
\hline $\begin{array}{c}\text { Formul } \\
\mathbf{a} \\
\text { Lotion }\end{array}$ & $\begin{array}{c}\text { Replika } \\
\text { si }\end{array}$ & $\begin{array}{c}\text { Kondisi } \\
\text { sebelum } \\
\text { dipercep } \\
\text { at }\end{array}$ & $\begin{array}{c}\text { Kondisi } \\
\text { setelah } \\
\text { dipercep } \\
\text { at }\end{array}$ \\
\hline \multirow{2}{*}{ Anionik } & 2 & Homogen & Homogen \\
\cline { 2 - 4 } & 3 & Homogen & Homogen \\
\hline \multirow{3}{*}{$\begin{array}{c}\text { Nonioni } \\
\mathbf{k}\end{array}$} & 1 & Homogen & Homogen \\
\cline { 2 - 4 } & 2 & Homogen & Homogen \\
\cline { 2 - 4 } & 3 & Homogen & Homogen \\
\hline
\end{tabular}

\section{Pengujian $\mathbf{p H}$}

Pengujian $\mathrm{pH}$ bertujuan untuk menilai apakah sediaan lotion aman atau tidak saat digunakan pada kulit.

Tabel 3 Data Hasil Pengujian pH Terhadap Lotion Tepung Tulang Sotong Sebelum dan Setelah Kondisi Dipercepat

\begin{tabular}{|c|c|c|c|}
\hline \multirow{2}{*}{$\begin{array}{c}\text { Formulasi } \\
\text { lotion }\end{array}$} & \multirow{2}{*}{ Replikasi } & \multicolumn{2}{|c|}{$\begin{array}{c}\text { Kondisi } \\
\text { dipercepat }\end{array}$} \\
\cline { 2 - 4 } & & Sebelum & Setelah \\
\hline \multirow{3}{*}{ Anionik } & 1 & 7 & 7 \\
\cline { 2 - 4 } & 2 & 7 & 7 \\
\cline { 2 - 4 } & 3 & 7 & 7 \\
\hline \multicolumn{2}{|r|}{ Rata-rata } & $\mathbf{7}$ & $\mathbf{7}$ \\
\hline \multirow{3}{*}{ Nonionik } & 1 & 6 & 6 \\
\cline { 2 - 4 } & 2 & 6 & 6 \\
\cline { 2 - 4 } & 3 & 6 & 6 \\
\hline \multicolumn{2}{|r|}{ Rata-rata } & 6 & 6 \\
\hline
\end{tabular}

Untuk lebih jelasnya mengenai data hasil pengujian $\mathrm{pH}$ terhadap lotion tepung tulang sotong sebelum dan setelah kondisi dipercepat, dapat dilihat pada grafik berikut:

Gambar 1 Diagram hasil uji $\mathrm{pH}$ sebelum dan setelah kondisi dipercepat

Dari hasil pengujian $\mathrm{pH}$ menunjukan bahwa formula Nonionik lotion tepung tulang sotong memiliki $\mathrm{pH}$ yang baik yaitu 6 dan tidak mengalani perubahan sesudah dipercepat. Maka dapat dikatakan bahwa lotion tersebut aman digunakan karena $\mathrm{pH}$ sediaan berada pada pH kulit, yaitu 4,5-6,5. (Balsam, 1972).

Sedangkan hasil pengujian $\mathrm{pH}$ formula Anionik lotion tepung tulang sotong memiliki $\mathrm{pH}$ yang baik pada kondisi sebelum dan setelah dipercepat yaitu 7 . Akan tetapi hasil pengujian menunjukkan bahwa formua lotion Anionik memiliki $\mathrm{pH}$ diatas $\mathrm{pH}$ normal kulit dengan range 4,5-6,5. Terdapat hubungan antara $\mathrm{pH}$ normal kulit 
dengan $\mathrm{pH}$ sediaan dikaitkan dengan beberapa aspek dermatologis seperti penetrasi, emolien dan iritasi. Pelindung kulit yang bersifat asam bertindak sebagai pelindung kimiawi terhadap bakteri, jamur serta berkapasitas sebagai buffer terhadap bahan-bahan yang bersifat basa (alkali). Jadi dapat dikatakan $\mathrm{pH}$ merupakan faktor terpenting dalam penerimaan kulit tubuh untuk suatu lotion, dan sedapat mungkin $\mathrm{pH}$ suatu lotion dapat dibuat mendekati $\mathrm{pH}$ normal kulit.

\section{Pengujian Iritasi Sediaan}

Pengujian iritasi sedian

bertujuan untuk mengetahui reaksi

sediaan yang terjadi pada kulit.

Tabel 2 Data Hasil Pengujian Iritasi Sediaan Terhadap Lotion Tepung Tulang Sotong Sebelum dan Setelah Kondisi Dipercepat

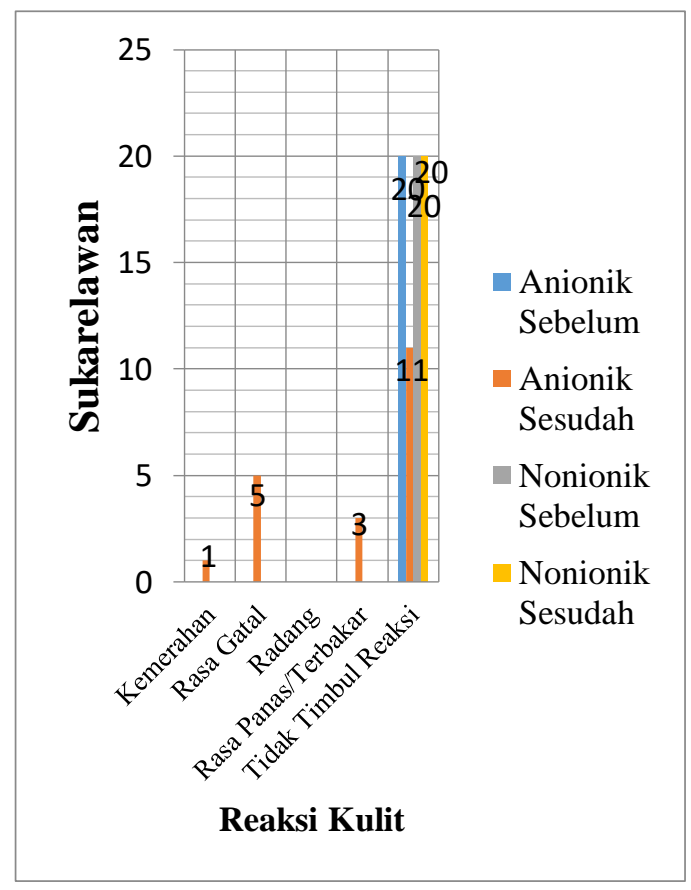

Gambar 2 Diagram hasil uji iritasi sediaan sebelum dan setelah kondisi dipercepat

Dari hasil pengujian dapat dilihat bahwa uji iritasi sediaan yang dilakukan terhadap 20 orang sukarelawan pada lotion tepung tulang sotong formula Nonionik dengan cara dioleskan ke kulit selama 5 menit menunjukan lotion tidak menimbulkan iritasi karena tidak adanya gejala timbul warna kemerahan, rasa gatal, rasa panas, dan timbul radang pada kulit pada kondisi sebelum dipercepat dan setelah dipercepat. Namun 1-20 sukarelawan yang menggunakan lotion tepung tulang sotong formula Anionik menunjukan reaksi kulit seperti warna kemerahan, rasa gatal, rasa panas. Hal ini mungkin disebabkan adanya perbedaan jenis kulit pada masingmasing sukarelawan dan mungkin juga disebabkan adanya kerusakan bahan saat kondisi dipercepat.

\section{KESIMPULAN DAN SARAN}

\section{Kesimpulan}

Berdasarkan hasil penelitian, dapat disimpulkan bahwa:

1. Tepung tulang sotong dapat dibuat sediaan lotion yang baik.

2. Lotion tepung tulang sotong pada formula nonionik dengan konsentrasi (Span $60 \quad 3 \%$ dan Tween $80 \quad 10 \%)$ menghasilkan lotion yang paling baik dibandingkan formula anionik (asam stearat 8\% dan TEA 4\%) dilihat dari uji $\mathrm{pH}$ dan uji iritasi sediaan.

\section{Saran}

Berdasarkan penelitian yang telah dilakukan, disarankan

1. Kepada peneliti selanjutnya untuk membuat lotion tepung tulang sotong dengan variasi konsentrasi emulgator nonionik dan 
memformulasikan tepung tulang sotong dalam bentuk sediaan lain.

2. Kepada masyarakat, agar bisa lebih memanfaatkan tepung tulang sotong dan dapat menggunakan tepung tulang sotong sebagai tabir surya secara tradisional.

\section{DAFTAR PUSTAKA}

Anief, M., 2007, Farmasetika,Gadjah Mada University Press, Yogyakarta

Anief, Moh. 1997. Formulasi Obat Tropikal Dengan Penyakit Kulit, Universitas Gadjah Mada Pres, Yogyakarta

Ansel, H.C., 1989, Pengantar Bentuk Sediaan Farmasi, terjemahan Farida Ibrahim, UI Press, Jakarta

Ash, I, dan Michael, 1977, A Formulary of Cosmetic Preparation, N.Y. chemical publishing Co, New York

Balsam, M.S. danE. Sagarin , 1972, Cosmetics Science and Technology, Second Edision, Volume 1, wiley-interscience a division of Jhon Wiley and Sons. Inc, New York-LondonSydney-Toronto, 44, 68, 181210

Birchall, J.D. and Thomas, N.L., 1983. On The Architecture and Function Of Cuttlefish Bone. Journal Of Materials Sciense. 18: 2081-2086.
Boyland J.C,1986, Hand Book of Pharmaticeutical Excipient, Amerika Pharmaceutical Association, Washington

Departeman Kesehatan RI, 1979, Farmakope Indonesia EdisiIII, Ditjen POM Depkes RI, Jakarta

Genarro, A.R, 1990, Remingtons Pharmaceutical Sciences, Eighteeth Edition, Ealson Mack Publishing Company, Pennsylvania

Joshita, 2008 , KestabilanObat,http://staff.ui.a c.id, diaksestanggal 30 November 2012

Lachman, L., 1994, Teori dan Praktek Farmasi Industri, terjemahan Siti Suyatmi, UI Press, Jakarta

Martin, Alfred, James Swarbrick, Arthur Cammarata, 1993, Farmasi Fisik, Jilid 2, Edisi ketiga, Universitas Indonesia Press, Jakarta, 11541157,1163

Rhicocean. 2010. Sotong. http://www.cephbase.utmb.edu /. Diakses tanggal28 November 2012.

Roper CFE, Sweeney MJ danNauen CE. 1984. Chepalopods of the World. FAO Species Catalogue 3(125): 277.

Santoso, Djoko dan Gunawan. 2003. Ramuan Tradisional Untuk Penyakit Kulit, Penebar Swadaya, Jakarta

Tahir I, Jumina, Yuliastuti I. 2002. Analisis Aktivitas Perlindungan Sinar UV 


\author{
secara In Vitro dan In Vivo \\ dari Beberapa Senyawa \\ Ester Sinamat Produk \\ Reaksi Kondensasi \\ Benzaldehida Tersubstitusi \\ dan Alkil Asetat. Makalah \\ pada Seminar Nasional \\ Kimia XI. Yogyakarta. \\ Jurusan Kimia FMIPA \\ UGM.
}

Yildrim. O.S., Okumus, Z., Kizilkaya,

M., Ozdemir, Y., Durak,

R., and Okur, A., 2007.

Comparative Quantitative

Analysis of Sodium,

Magnesium, Potassium and

Calcium In Healthy

Cuttlefish Backbone and

Non-Pathological Human

Elbow Bone. Canadian

Journal of Analytical

Sciences and Spectroscopy.

52(5): 270-275. 